\title{
The Problems of Urban Planning Evolution of Khabarovsk City and their Solution Through Ecological Renovation
}

\author{
Yulia Igorevna Ermakova*
}

\author{
Institute of Geography, RAS, Moscow, Russia \\ *Corresponding author. Email: ermakova@igras.ru
}

\begin{abstract}
The article highlights the main stages of the urban development of Khabarovsk. The analysis of potentially dangerous natural factors is presented. The approaches to the development of the territory characteristic of each stage are analyzed. The spatial and temporal development of the city's planning system is clearly presented. Modern environmental risks are highlighted. The prospects for the formation of a stable and comfortable urban environment are evaluated. A method of solving environmental problems in the territory of Khabarovsk by renovation based on the principles of green construction is proposed.
\end{abstract}

Keywords: Khabarovsk city, planning system, ecological and urban development, sustainability and comfort of the urban environment, ecological renovation, living environment of the population.

\section{INTRODUCTION}

The territory of the south of the Far East is under the influence of a number of negative natural landscape factors that have had a limiting effect on the development of the region. The formation of the city of Khabarovsk has always been complicated by the remoteness from the central regions of Russia, as well as the proximity to China. Historical analysis allows us to identify four stages in the development of the planning system of Khabarovsk: pre-industrial, industrial, socialist, modern. Each of these stages is characterized by a fundamental difference in goals and approaches to the development of the territory. As a result, at each stage, a unique set of anthropogenic impacts and their consequences for the environment can be traced. The general principles of the stage of urban development have been consistently entrenched in the city building. If at the beginning of the formation of the city the landscape of the area was the main regulator of development and a limiting environmental factor, then as the society industrialized, the landscape lost its decisive role, undergoing profound change everywhere. The peak of the aggressiveness of anthropogenic impact, falling on the years of Soviet power, led to the loss of natural landscapes on the territory of Khabarovsk. It was at this time that the maximum aggravation of the conflict between the living environment of the population and potentially dangerous natural factors occurred. Thus, the dominance of the Siberian anticyclone in cold months significantly aggravates the pollution of the city's atmosphere. At the industrial stage of the development of the planning system of Khabarovsk, complex ecological and urban planning problems were laid, which determine the low quality of the living environment of the population today. Against the background of global changes in nature, such as more frequent floods on the Amur River and the COVID-19 pandemic, the life of society is also changing. Urban planning is one of those strategic areas on which the future of individual countries and humanity as a whole depends. The organization of a stable and comfortable living environment in the cities of the Far East is the most important task in the struggle to preserve human resources in the region. Traditional planning solutions are rapidly failing to justify themselves. At the moment, Khabarovsk, like the whole world, is faced with the need to revise the mistakes of the industrial past. The current stage of the city's development opens up prospects for a radical change in the urban planning structure towards greening. The new general plan of Khabarovsk makes it possible to form the natural and ecological framework of the city, which will no longer be a form of environmental protection, but a tool for environmental management. On the way to this, a method of ecological renovation is proposed, the essence of 
which is to transform neighborhoods, vast territories of which are occupied by low-rise dilapidated housing stock and garages, and weakened woody plants of weed views prevail in the green cover.

\section{MATERIALS AND METHODS}

The study used cartographic and statistical materials provided by the Russian Institute of Urban Planning and Investment Development «Giprogor» and the Institute of Water and Environmental Problems of the Far Eastern Branch of the Russian Academy of Sciences. The processing of the initial data was carried out by the methods of classification, modeling and urban planning. The spatiotemporal model of the development of the planning structure of Khabarovsk was created in a GISsurroundings. The development of the site for green renovation was carried out with the help of the computeraided design software AutoCAD. The proposed method for improving the urban environment of Khabarovsk is based on the ecological and urban planning approach. Its goal is environmental activities in terms of territorial planning.

\section{RESULTS AND DISCUSSION}

The reduced quality of the living environment of the population in the city of Khabarovsk is determined by a number of factors. Among them is the peripheral position of the Far Eastern region, difficult natural and climatic conditions, industrial urban development past. An indicator of the aggravation of economic problems in such a situation is immediately the outflow of the population. Thus, the decrease in the population of Khabarovsk at the end of the twentieth century is associated with the general crisis of the Far East during the fall of the USSR. The jump in the population after 2008 is due to the recovery of the Russian economy and the introduction of programs for the advanced development of the Far Eastern Federal District, where the city of Khabarovsk is identified as one of the growth points. The decrease in the number of population since 2019 is due to the loss of Khabarovsk status as the administrative center of the Far East and the economic consequences of this decision. The main reasons for migration from Khabarovsk are a drop in income levels, the cost of goods (primarily food) and services, not commensurate with quality, outdated education, and inaccessibility of housing. Most often young specialists leave the region $[19,20,21]$.

The historically entrenched pattern between the outflow of the population in response to economic difficulties proves the particular vulnerability of the region. The reduced quality of the living environment in Khabarovsk is aggravated by the difficult ecological situation, which, in turn, is due to the neglect of a number of decisive natural and landscape factors in urban planning. During the development of the industry throughout the twentieth century, these factors have acquired a potentially dangerous nature:

1. Relief. The city of Khabarovsk is surrounded by mountain ranges, which directly contributes to the stagnation of harmful impurities in the atmosphere. The most acute situation with air pollution is in the area of industrial enterprises, which are confined to local relief depressions (Khabarovsk Oil Refinery). In general, 56.7\% of the territory of Khabarovsk occupies the surface of the flat, slightly sloping III above-floodplain terrace of the Amur River [11]. This situation contributes to the unhindered spread of air pollution over large areas;

2. The dominance of the Siberian anticyclone in the cold season (November-March). This factor significantly aggravates the influence of the relief. Dry, clear weather with a consistently high atmospheric pressure contributes to the concentration of harmful impurities in the atmosphere. The air basin of the city is practically not cleaned. The snow cover is almost not formed, it is subject to pollution until spring. The main impurity in the atmosphere of Khabarovsk is suspended particles. Their content increases in proportion to the growth of cars [2,15]. The reason for the decrease in air pollution in summer is active cyclonic activity. The excess of the summer precipitation rate contributes to the natural purification of the atmosphere. However, the flood situation directly depends on the amount of summer precipitation in the Amur River basin;

3. Summer-autumn floods. Significant fluctuations in the water level in the Amur River are caused by monsoon rains, which account for up to $75 \%$ of the annual runoff. During the period of heavy showers, the water level stays at a speed of up to $30 \mathrm{~cm}$ per hour, spills reach $10-25 \mathrm{~km}$ and last up to 70 days $[1,2,15]$. More frequent floods are also caused by abnormal changes in the circulation of air masses over the south of Siberia and the Far East, which may become permanent. An imbalance in the mechanism of circulation of air masses contributes to the formation of powerful cyclones with a longer period of existence [9]. The trend towards more frequent destructive floods is confirmed by the fact that in 2009 the Amur River entered a period of increased water $[9,17]$;

4. Potential fire hazard in the south of the Far East. The emergence of natural fires is facilitated by the pollution of the atmosphere with dusty particles, which enter the temperate latitudes with dry heated air masses from Mongolia at the beginning of summer; minimum reserves of moisture in the soil associated with little snow in winter [18]. The increase in forest fires in the south of the Far East is explained by the increasing role of the Earth's climate warming over the past 20 years. The atmosphere of Khabarovsk in the summer-autumn period is often exposed to smoke. 
Ignoring the influence of negative natural factors on the ecological situation can lead to irreversible consequences for the health of the population. To preserve human resources in the Far East region, it is necessary not only to have an effective economic policy, but also to create a healthy living environment. The main indicator of such an environment is physical, psychological and social comfort. Improvement of environmental indicators in Khabarovsk over the past decade is associated with environmental measures: modernization of the main treatment facilities, bus fleet; transfer of urban thermal power to gas fuel [4,7]. However, against the background of modern environmental challenges, this is not enough. A radical systemic transformation of the urban planning structure from postindustrial to noospheric is needed.

In order to identify potential obstacles that will arise in the process of transforming the living environment, a detailed analysis of the urban development of Khabarovsk was carried out, which revealed the key factors in the formation of its appearance. In the history of the development of the planning system of Khabarovsk, 4 stages of the development of the territory are distinguished. Each of them is characterized by a certain approach and a certain composition of the master plan.

The pre-industrial stage (1858-1880) was marked for urban planning by the decisive role of the landscape: relief is the main factor of development, the Amur River is the main dominant that carries a communication function. Initially, the river is the main planning axis along which the linear development of the settlement goes. Later, the development of the central streets takes place inland from the river, along the ridges of three spurs of the Sikhote-Alin mountain system, laying the features of a regular layout in the general plan.
The industrial stage (1880-1917) was marked by the final formation of a regular layout due to the gradual development of inconveniences - ravines between central streets. The main planning axis and transport artery is now the Trans-Siberian Railway, in the places of service of which new functional zones are emerging. The first industries and settlements of workers began to develop along its axis.

The socialist stage (1917-1991) is an example of a sharp change in urban planning paradigms. The landscape finally loses the role of the decisive factor in the design. In a short time, the city becomes a site for the location of production. The priority is set for mass residential development. There is a separation of residential and industrial zones. Transport does not serve to connect urban areas, but provides labor for production. These processes were reflected in the transformation of the master plan. Its composition first takes on the features of a dismembered system (industrial units and workers' settlements around them are scattered). Then the planning system becomes linear again (a continuous industrial belt appears). Due to the length of the city for $33 \mathrm{~km}$ and the tightness between the river and the railway, the problem of transport communication is being laid. The northern and southern parts of the city are poorly connected. Also, communication between the periphery and the historical center, where business activity is concentrated, is difficult. The Amur River becomes isolated by an industrial and warehouse complex, depriving the townspeople of the visual aesthetics of the landscape. The natural landscape within the city has been lost. At the end of the socialist stage, the crisis of the industrial urban planning system becomes
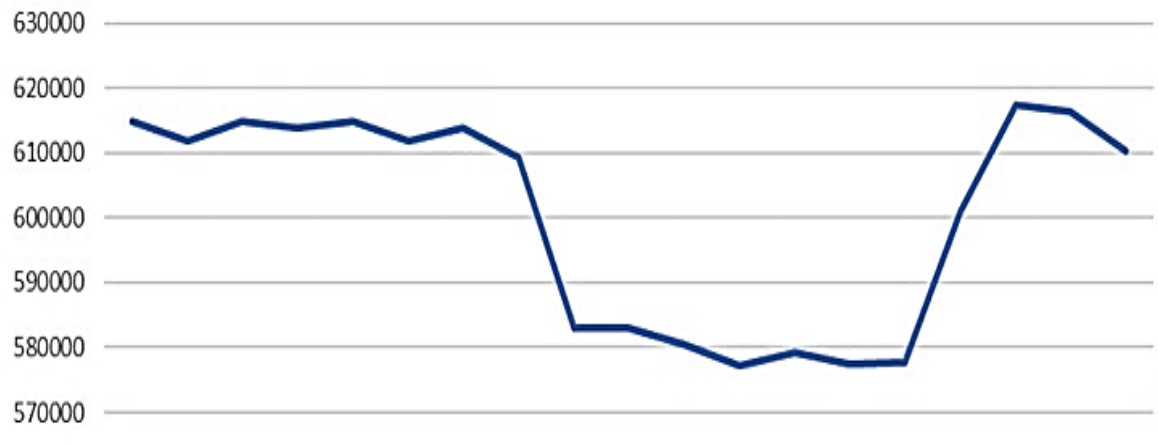

560000

550000

1992199319941996199719981999200020022003200420082009201020112014201920202021

\section{- Number'of'peopleף}

Figure 1 The graph of changes in the population of the city of Khabarovsk from 1992 to the present time 
Table 1. Stages of the historical development of Khabarovsk and anthropogenic impact on the landscape.

\begin{tabular}{|c|c|c|c|c|}
\hline $\begin{array}{l}\text { Devel } \\
\text { opme } \\
\text { nt } \\
\text { stage }\end{array}$ & $\begin{array}{l}\text { Components } \\
\text { of the urban } \\
\text { landscape }\end{array}$ & Anthropogenic impact & $\begin{array}{l}\text { Max. } \\
\text { num. } \\
\text { population }\end{array}$ & Environmental impact \\
\hline \multirow{5}{*}{ 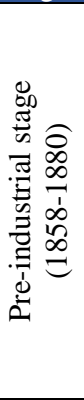 } & $\begin{array}{l}\text { Geological and } \\
\text { geomorphological }\end{array}$ & $\begin{array}{l}\text { Construction of wooden buildings } \\
\text { without a radical transformation } \\
\text { of the relief }\end{array}$ & \multirow{5}{*}{ 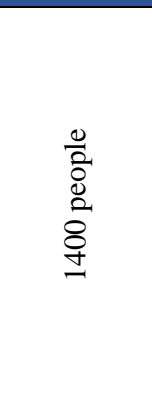 } & \multirow{5}{*}{$\begin{array}{l}\text { Insignificant loss of the } \\
\text { natural landscape in the } \\
\text { developed areas, } \\
\text { pollution } \\
\text { of the water, soil and air } \\
\text { environment. Reducing } \\
\text { biodiversity }\end{array}$} \\
\hline & Air & $\begin{array}{c}\text { The use of solid fuel in everyday } \\
\text { life and in river shipping }\end{array}$ & & \\
\hline & Water & \multirow{2}{*}{$\begin{array}{l}\text { Disposal of household waste, } \\
\text { butchery waste and fishery waste }\end{array}$} & & \\
\hline & Soil & & & \\
\hline & Biotic & $\begin{array}{l}\text { Destruction of vegetation cover } \\
\text { on built-up elevations }\end{array}$ & & \\
\hline \multirow{5}{*}{ 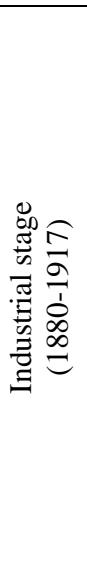 } & $\begin{array}{l}\text { Geological and } \\
\text { geomorphological }\end{array}$ & $\begin{array}{l}\text { Change of relief in the area of } \\
\text { construction of the Trans-Siberian } \\
\text { railway, construction of wooden } \\
\text { and stone buildings without } \\
\text { cardinal changes in the relief }\end{array}$ & \multirow{5}{*}{$\begin{array}{l}\frac{0}{2} \\
\frac{0}{0} \\
\frac{0}{2} \\
\frac{0}{n}\end{array}$} & \multirow{5}{*}{$\begin{array}{l}\text { The expansion of the } \\
\text { developed territory } \\
\text { leads to an increase in } \\
\text { pressure on the natural } \\
\text { landscape. Reducing } \\
\text { biodiversity }\end{array}$} \\
\hline & Air & $\begin{array}{l}\text { The use of solid fuel in everyday } \\
\text { life, river shipping, railway } \\
\text { transport and early production }\end{array}$ & & \\
\hline & Water & \multirow{2}{*}{$\begin{array}{l}\text { Disposal of household waste, } \\
\text { butchery waste and fishery waste, } \\
\text { first production waste }\end{array}$} & & \\
\hline & Soil & & & \\
\hline & Biotic & $\begin{array}{l}\text { Destruction of vegetation cover in } \\
\text { built-up areas, including marginal } \\
\text { lands }\end{array}$ & & \\
\hline \multirow{5}{*}{ 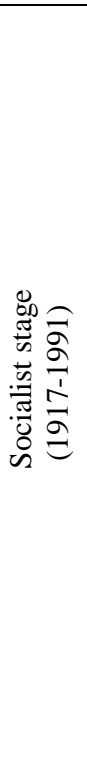 } & $\begin{array}{l}\text { Geological and } \\
\text { geomorphological }\end{array}$ & $\begin{array}{l}\text { Total transformation of the } \\
\text { relief in the area of industrial } \\
\text { zones and mass housing } \\
\text { construction. Increasing the } \\
\text { number of storeys in buildings. } \\
\text { Increase in paved surfaces. } \\
\text { Formation of a new contour of } \\
\text { the Amur River coastline }\end{array}$ & \multirow{5}{*}{ 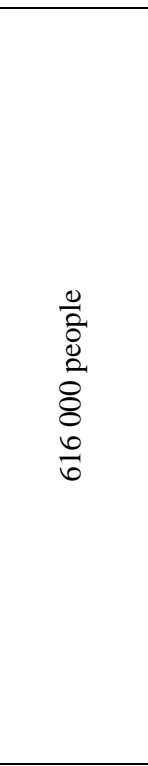 } & \multirow{5}{*}{$\begin{array}{c}\text { Loss of natural } \\
\text { landscapes within the } \\
\text { city. Activation of } \\
\text { dangerous geological } \\
\text { processes. } \\
\text { Displacement of Far } \\
\text { Eastern vegetation } \\
\text { species by weeds. The } \\
\text { appearance of } \\
\text { temperature inversions. } \\
\text { Poor drinking water } \\
\text { quality. Strong air } \\
\text { pollution, aggravated by } \\
\text { the prevalence of } \\
\text { anticyclone in the cold } \\
\text { season. Exacerbation of } \\
\text { diseases caused not only } \\
\text { by the climate, but also } \\
\text { by the environmental } \\
\text { factor. Reducing } \\
\text { biodiversity }\end{array}$} \\
\hline & Air & $\begin{array}{c}\text { Industrial and transport air } \\
\text { pollution with soot and } \\
\text { exhaust gases } \\
\end{array}$ & & \\
\hline & Water & \multirow{2}{*}{$\begin{array}{l}\text { Discharge of untreated industrial } \\
\text { and sewage effluents. Dumps } \\
\text { formation }\end{array}$} & & \\
\hline & Soil & & & \\
\hline & Biotic & $\begin{array}{l}\text { Formation of anthropogenic } \\
\text { wastelands devoid of vegetation. } \\
\text { Replacement of indigenous } \\
\text { vegetation with urban plantings }\end{array}$ & & \\
\hline \multirow{5}{*}{ 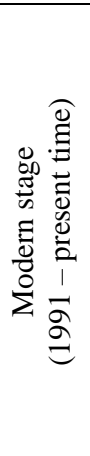 } & $\begin{array}{l}\text { Geological and } \\
\text { geomorphological }\end{array}$ & $\begin{array}{l}\text { Capital sealing construction of } \\
\text { multi-storey buildings. Coastal } \\
\text { flood protection measures }\end{array}$ & \multirow{5}{*}{ 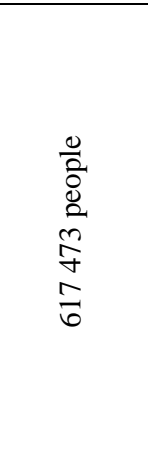 } & \multirow{5}{*}{$\begin{array}{l}\text { The need to search for } \\
\text { ways to restore the } \\
\text { natural landscape, } \\
\text { search for the } \\
\text { possibility of purifying } \\
\text { the air basin and } \\
\text { alternative sources of } \\
\text { drinking water. } \\
\text { Attempts to restore of } \\
\text { biodiversity }\end{array}$} \\
\hline & Air & $\begin{array}{l}\text { Reduction of the use of solid } \\
\text { fuels, conversion of enterprises to } \\
\text { gas. Prevailing emissions from } \\
\text { road transport }\end{array}$ & & \\
\hline & Water & \multirow{3}{*}{$\begin{array}{c}\text { Reduction of effluents. Landfill } \\
\text { reclamation. Modernization of } \\
\text { treatment facilities and water } \\
\text { supply system }\end{array}$} & & \\
\hline & Soil & & & \\
\hline & Biotic & & & \\
\hline
\end{tabular}




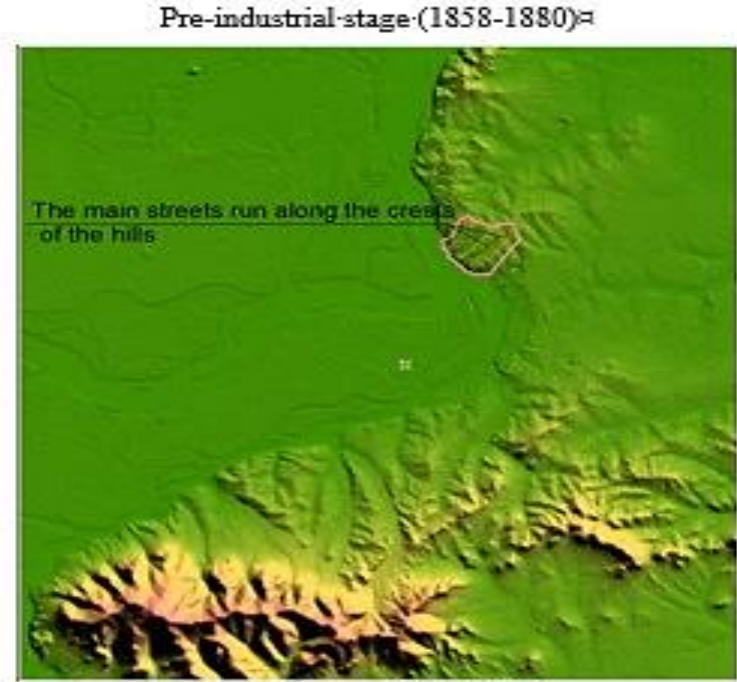

Socialist-stage-(1917-1991)a

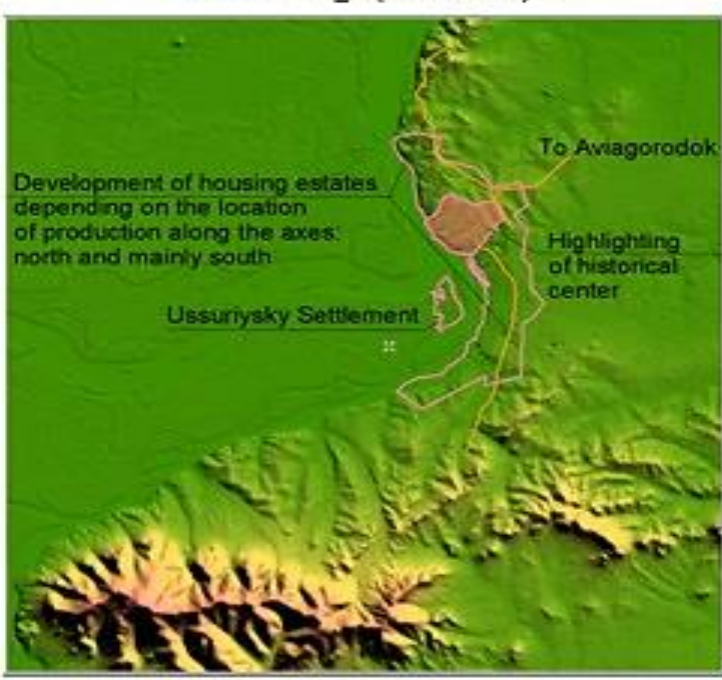

Legend:

city boundaries

main planning axes

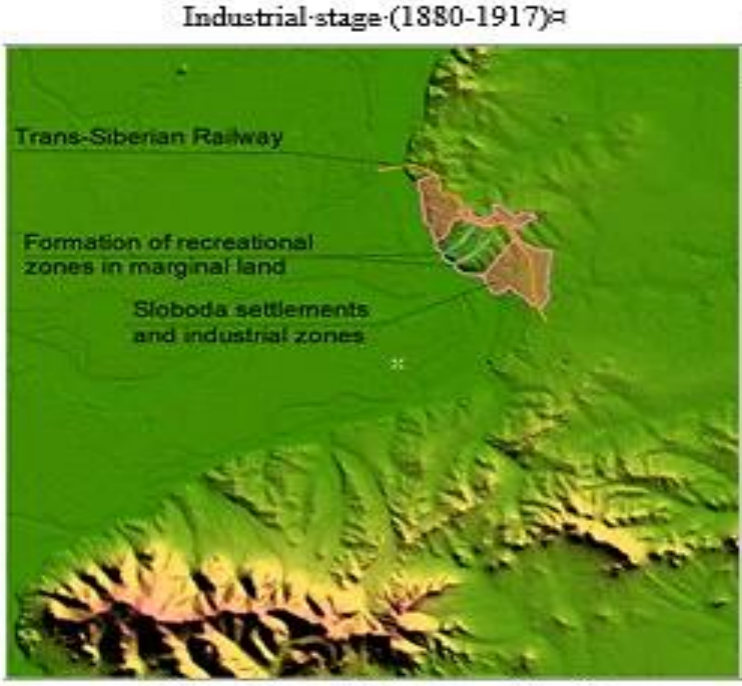

Modern'stage $\cdot(1991$-present time) $=$

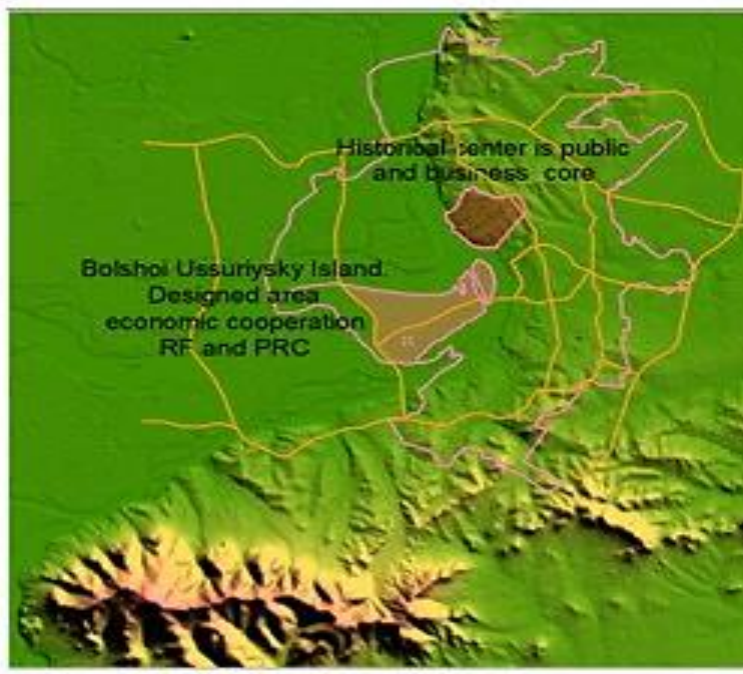

Formation of ring structures for unloading the main highways and communication of the old-developed (right-bank) and new (left-bank) parts of the city

Figure 2 Spatiotemporal model of the evolution of the planning system of the city of Khabarovsk

riverside territories the lost landscape and recreational meaning.

The modern stage of the urban development of Khabarovsk (1991-present time) is expressed in the search for a balance between the natural and anthropogenic components of the environment. The legacy of industrialization is represented by the mosaic nature of the layout, functional heterogeneity, heterogeneity of landscaping, a small number of roads connecting the center with the outskirts. The historical center is oversaturated with infrastructure institutions, commercialized, while in the periphery there is a shortage of infrastructure and opportunities for leisure. The roads connecting the center and the outskirts are congested with personal and public transport. The city faced the problem of serious traffic congestion.
There is a need to form support frames (natural and ecological, industrial, etc.), which will become a single tool for managing the urban system. Such a radical transformation of the general plan, such as the introduction of ring structures into a linear planning system, opens up prospects for the greening of urban planning. The bypass diameters cover the left bank of the Amur and part of the Bolshoi Ussuriysky Island, where the zone of cooperation between Russia and China is located. The development of transport infrastructure in these territories not only relieves the main city highways from traffic congestion. These territories also carry out neutralizing environmental impacts on the urban environment. They are promising for the implementation of green construction projects in the Khabarovsk structure, however, subject to the observance of preliminary measures against floods. 
The urban planning system of the city of Khabarovsk is presented in the form of a spatiotemporal model of the development of the main planning elements. The digital model of the terrain clearly shows the change in the boundaries of the city and the main planning axes $[3,5$, $6,10,11,12,14]$.

In the context of the ecological and urban planning approach to improving the living environment of the population, a method of ecological renovation as a landscape reconstruction is proposed. The purpose of the method is to reduce the anthropogenic load, restore the natural landscape and its properties within the city. This event on the territory of Khabarovsk is justified by the problem of vast areas occupied by dilapidated housing stock, garages, wastelands with spontaneous dumps, weakened by time and weedy woody vegetation. The population density of such neighborhoods is extremely low. Often, such territories are located in close proximity to the social and business core of the city - the historical center, which makes their transformation commercially profitable.

The essence of the method of ecological renovation is to free areas from outdated (often emergency) low-rise housing with the further relocation of citizens to modern comfortable houses, erected on a vacant plot of the same territory even before the demolition of old buildings. New housing implies capacity and compactness: more floors, a landscaped adjoining territory and a parking area in a smaller area than before. Thus, valuable areas are freed up inside the quarter, where it is possible to restore the natural landscape of the geographical area. The necessary measures for this are a complete renewal of the species composition of plants and individual elements of engineering systems, the calculation of the optimal recreational load.

In the urban landscaping of Khabarovsk, local types of vegetation are extremely poorly represented, despite the fact that the forest ecosystems of the south of the Far East are unique. They are characterized by such features as great species diversity per unit of space, gigantism, endemicity and relict nature. Ecosystems with similar properties, due to the richness of species, have a huge potential for the formation of environmental sustainability.

\section{CONCLUSION}

The Far East is of great strategic importance for Russia, the territory needs human resources, especially modern young specialists, without whom the economic growth of the region is impossible. The remoteness of Khabarovsk from the political center of the country narrows the range of development opportunities for both the city as a whole and its population. Peripheral living conditions are aggravated by unfavorable natural and climatic factors. This has historically been the reason for the outflow of the population in the event of a worsening economic situation.

Finding a solution to this problem dictates the need to mitigate the harsh environmental conditions. Improving the quality of life of the population should be comprehensive and cover all areas. Improving the living environment begins with improving the ecological situation. The town-planning system is a stable basis for environmental transformations, since the town-planning and ecological components in the urban «organism» are inseparable.

The historical analysis of the evolution of the planning system of Khabarovsk from the point of view of the ecological and urban planning approach made it possible to identify some patterns. The first stages of the development of the territory of Khabarovsk were less aggressive in terms of the degree of anthropogenic impact due to the limiting role of the relief during construction. The outstripping rates of development of production at the socialist stage crushed the role of the relief as a limiting factor. As a result, a total change in space led to the destruction of natural landscapes within the city. The living environment of the population suffered the greatest environmental damage. At that moment, a cascade of problems was launched, with which the city continues to struggle today.

The ecological renovation method is quite new. It is often interpreted by architects as a solution to environmental problems by planting greenery on individual sites. However, this method undoubtedly has a stronger potential, and it can form the basis of a program for the restoration of lost landscapes in the territory of the city of Khabarovsk, and then - for the formation of a natural-ecological framework as a tool for managing the urban system. Subject to the success of the events, we will get a modern Far Eastern city with a more comfortable environment for life.

The article was prepared on the topic of State Assignment No. 0148-2019-0007 «Assessment of physical-geographical, hydrological and biotic changes in the environment and their consequences for creating the foundations of sustainable nature management».

\section{REFERENCES}

[1] S.A. Ageeva, I.V. Bobrikova, E.M. Verbitskaya, N.F. Efremova, S.O. Romansky, Causes and features of the formation of a catastrophic flood on the Amur in the summer of 2013. Third Vinogradov readings. Facets of hydrology, In: Collection of reports of the international scientific conference in memory of the outstanding Russian hydrologist Yuri Borisovich Vinogradov, 2018.

[2] Amendments to the master plan of the urban district «City of Khabarovsk», In: Materials on the 
substantiation of the draft master plan of the urban district «City of Khabarovsk». Hyprogor, 2017.

[3] Yu.I. Ermakova, B.I. Kochurov, Ecological and urban planning aspect of the development of Khabarovsk in the conditions of changes in nature and society. Ecology of urbanized territories 1 (2020) pp. 49-59.

[4] E.M. Klimina, Landscape and cartographic support of territorial planning (on the example of the Khabarovsk Territory). Dalnauka, 2007, p. 132.

[5] B.I. Kochurov, Eco-diagnostics and balanced development. Publishing House «Infra-M», 2016, p. 362 .

[6] B.I. Kochurov, V.A. Lobkovsky, Smirnov A.Ya. Efficiency and culture of environmental management. OOO Rusays, 2018, p. 162.

[7] O. V. Kuznetsov, G.Ya. Markelov, Assessment of green spaces in Khabarovsk using remote sensing data and Gis-technologies. Geomatics 18 (2013).

[8] M.A. Matashova, Ecological and urban planning optimization of riverside territories: on the example of Khabarovsk: dissertation of the candidate of architecture. Moscow Architectural Institute, 2011.

[9] A.N. Makhinov, V.I. Kim, B.A. Voronov, Historical flood in the Amur basin in 2013: causes and consequences. Vestnik FEB RAS 2 (2014) p. 5.

[10] G.Yu. Morozova, N.A. Narbut, A.A. Baburin and others, The concept of landscaping Khabarovsk. IWEP FEB RAS, 2003, p. 38.

[11] N.A. Narbut, L.A. Antonova, L.A. Matyushkina, E.M. Klimina, K.P. Karavanov, The strategy for the formation of the ecological framework of the territory (on the example of Khabarovsk). FEB RAS, 2002, p. 129.

[12] N.A. Narbut, Features of environmental policy in the regions of new development. Regions of new development: natural successions and anthropogenic transformation of natural complexes, In: Conference materials with international participation. FGBUN Institute of Water and Environmental Problems FEB RAS, 2017, pp. 208-210.

[13] A.P. Nikolaev, D.A. Nikolaev, About the planning project of the city of Khabarovsk in the light of the prospects for urban development of the left bank and the Amur Islands, In: Materials of the 4th AllRussian conference «Urban planning and planning of territorial development of Russia», 2006, pp. 19-22.

[14] Portal of the administration of the city of Khabarovsk. https://www.khabarovskadm.ru/.
[15] Resolution of November 01, 2013 No. 4440 On approval of the municipal program «Improving the ecological state of the city of Khabarovsk» for 20142020, 2017.

[16] P.Ya. Baklanov, S.S. Hanzea, Problems of sustainable use of transboundary territories, In: Proceedings of the international conference. TIG FEB RAS, 2006, p. 176.

[17] Flood-2019 in Khabarovsk is recognized as the second strongest in the history of measurements. https://todaykhv.ru/news/society/22069/09/24/2019.

[18] G.V. Sokolova, E.P. Teteryatnikova, Problems of long-term forecasting of fire hazard in the forests of the Khabarovsk Territory and the Jewish Autonomous Region based on meteorological conditions. FEB RAS, 2008, p. 150.

[19] Strategy of socio-economic development of the Khabarovsk Territory for the period up to 2030. Government of the Khabarovsk Territory, 2017.

[20] Points of growth. Russian newspaper. Economy of the Far East 5(8356). https://rg.ru/2021/01/14/regdfo/v-habarovskom-krae-zabuksoval-proektpomoshchi-molodym-specialistam.html.

[21] Difficult region. Rossiyskaya Gazeta - Stolichny Issue 0(4844). https://rg.ru/2009/02/09/region.html. 